\title{
Evaluation of binding properties of Plantago psyllium seed mucilage
}

\author{
MAJID SAEEDI ${ }^{1,2, *}$ \\ KATAYOUN MORTEZA-SEMNANI ${ }^{2,3}$ \\ FARSHAD ANSOROUDI ${ }^{1}$ \\ SAEED FALLAH ${ }^{1}$ \\ GHOLAMREZA AMIN ${ }^{4}$ \\ 1 Department of Pharmaceutics, Faculty \\ of Pharmacy, Mazandaran University \\ of Medical Sciences, Sari, Iran \\ 2 Pharmaceutical Sciences Research \\ Center, Mazandaran University of \\ Medical Sciences, Sari, Iran \\ ${ }^{3}$ Department of Medicinal Chemistry \\ Faculty of Pharmacy, Mazandaran \\ University of Medical Sciences, Sari, Iran \\ ${ }^{4}$ Department of Pharmacognosy, Faculty \\ of Pharmacy, Tehran University of \\ Medical Sciences, Tehran, Iran
}

\begin{abstract}
Mucilage extracted from Plantago psyllium seeds was evaluated for inertness and safety parameters. The suitability of psyllium mucilage for a pharmaceutical binder was assessed in paracetamol tablets. Properties of the granules prepared using different concentrations of psyllium mucilage was compared with PVP and tragacanth. Psyllium mucilage at $5 \%(\mathrm{~m} / \mathrm{m})$ was found to be comparable with $3 \%(\mathrm{~m} / \mathrm{m})$ of PVP. Investigated paracetamol tablets indicated that psyllium mucilage can retard the drug release.
\end{abstract}

Keywords: Plantago psyllium (Plantaginaceae), mucilage, paracetamol, binder, release

Accepted July 28, 2010

Pharmaceutical ingredients are required in the preparation of a drug tablet: fillers to increase the bulk and lubricants to reduce friction during the tableting process. Some pharmaceutical ingredients require a binder for tableting. This provides the cohesiveness necessary for binding ingredient granules under compression. The quantity used must be carefully regulated, since the tablet must disintegrate after administration to liberate the drug (1). Binders act by causing aggregation of powders, thereby forming granules through the granulation process. They modify the cohesive properties of the granules by promoting the formation of strong cohesive bonds between such particles (2).

Mucilages and gums are well known for their medicinal use. In recent times, increasing attention has been given to the application of gums of various sources as phar-

* Correspondence; e-mail: majsaeedi@yahoo.com 
maceutical excipients. Plant gums and exudates are getting screened for their use as pharmaceutical adjuvants. Mucilages are generally polysaccharides, which are polymeric in nature and are obtained from woody and non-woody plant parts such as bark, seeds, sap, roots, rhizomes, fruits, and leaves. Mucilages are used for their binding, thickening, stabilizing, humidifying, disintegrating and release controlling properties in medicines (3). However, pharmaceutical adjuvants have stringent specifications, which few natural agents can fulfil. Tablet characteristics of any pharmaceutical material can be obtained from studies of its mechanical properties; such properties have been studied by various techniques based on their plastic and elastic behaviour during compression and/or decompression cycles (4).

Plantago psyllium L. (Plantaginaceae) comprises two valuable medicinal species of isabgol (Plantago ovata) and psyllium (Plantago psyllium). Seeds of Plantago psyllium L. form mucilage in the presence of water due to polysaccharides in the seed coat (5). Psyllium mucilage is an anionic polysaccharide of $L$-arabinose, $D$-xylose and $D$-galactoronic acid. Mucilage content of psyllium has been reported to be as high as 10-15\% (6). The present study investigates the binding properties of Plantago psyllium seed mucilage as a natural, safe, available and inexpensive binder and its effects on the mechanical properties of paracetamol granules and tablets. Paracetamol was chosen as a model drug showing elastic properties during tableting.

\section{EXPERIMENTAL}

\section{Materials}

Paracetamol (Rouzdaru Co., Iran) was received as a free sample. Lactose, polyvinylpyrrolidone (PVP), tragacanth and other ingredients were purchased from Merck Co. (Germany). Psyllium seeds (pharmaceutical grade) were obtained from herbal medicine centers (Sari, Iran).

\section{Swelling factor}

For determination of the swelling factor, psyllium seeds $(1 \mathrm{~g})$ were put into graduated stoppered cylinders, which were later filled with distilled water at room temperature (up to the $25 \mathrm{~mL}$ mark). Except for intermittent agitation, the cylinders were left undisturbed for $24 \mathrm{~h}$ and the volume of the swollen seed layer was then recorded by observing the water gel boundary. The test was done in triplicate and the mean results are shown (7).

\section{Preparation of mucilage}

Plantago psyllium seed was extracted according to Sharma and Koul's method (7). Ten milliliters of $0.1 \mathrm{~mol} \mathrm{~L}^{-1} \mathrm{HCl}$ were heated to boiling in a $100-\mathrm{mL}$ flask and $1 \mathrm{~g}$ of the dry seed test sample was added. Heating was resumed and the process of seed husk dissolution was watched. When all seeds had changed color, the flask was finally removed from the heat and the solution was filtered through clean muslin cloth, while still hot. In 
order to separate residual traces of mucilage, the seeds were washed twice with $5 \mathrm{~mL}$ of hot water and the solution obtained each time was filtered. The combined filtrate, containing the dissolved mucilage, was mixed with $60 \mathrm{~mL}$ of $95 \%$ ethyl alcohol, stirred and allowed to stand for $5 \mathrm{~h}$. Finally, the supernatant liquid was decanted and the precipitate in the beaker was dried in an oven at $50{ }^{\circ} \mathrm{C}$. The mass of dry precipitate was taken to represent the total mucilage content.

\section{Viscosity determination}

Dried and finely powdered psyllium mucilage $(1 \mathrm{~g})$ was suspended in $75 \mathrm{~mL}$ of distilled water for $5 \mathrm{~h}$. Distilled water was added to produce the concentration of $1 \%$ $(m / V)$. The mixture was homogenized with a mechanical stirrer for $2 \mathrm{~h}$ and its viscosity was determined using a Brookfield viscometer spindle (LV2, Brookfield, USA) at $20 \mathrm{rpm}$ and $25^{\circ} \mathrm{C}$.

\section{Preparation of granules}

Paracetamol powder (200 g) was wet massed with a given volume of the psyllium mucilage aqueous dispersion (1-5\%) in a planetary mixer (Erweka, Germany) and screened through a sieve $(0.84 \mathrm{~mm})$. PVP and tragacanth (1 and $3 \%)$ were used for comparison. Table I shows the investigated tablet ingredients. The resulting granules were dried to constant mass in a hot air oven (Shimifan, Iran) at $50{ }^{\circ} \mathrm{C}$ for $3 \mathrm{~h}$. The mean moisture content was found to be $2.8 \pm 0.9 \%(\mathrm{~m} / \mathrm{m})$.

\section{Preparation of tablets}

Several formulations containing psyllium mucilage (1-5\%) as binder were prepared by the granulation method. The granules made from either psyllium mucilage or PVP or tragacanth were compressed into flat-faced tablets using $12-\mathrm{mm}$ punches in a single punch tableting machine (Korsch, Germany) using $1 \%(\mathrm{~m} / \mathrm{m})$ magnesium stearate. After ejection, the tablets were stored over silica gel for $24 \mathrm{~h}$ to allow for elastic recovery and hardening.

\section{Evaluation of tablets}

The bulk density of each formulation at zero pressure (loose density) was determined by pouring the granules, at an angle of $45^{\circ}$, through a funnel into a glass measuring cylinder with a 24-mm diameter and a volume of $50 \mathrm{~mL}$. Determinations were done in triplicate. The relative density of each formulation was obtained from the ratio of its loose density to its particle density.

Other granule properties (percentage of fines, tapped density and porosity) and tablet properties (crushing strength, mass variation, friabilit and disintegration time) were determined by a standard procedure (8).

The tensile strength $(T)$ of tablets, which is a measure of the stress necessary to cause diametral fracture of the compact, was determined from the mean data obtained from 
the hardness test carried out on the tablets $(n=10)$ using the Erweka hardness tester (TBH 30MD, Germany). The $T$ values were computed from the equation (9):

$$
T=\frac{2 P}{\pi D t}
$$

where $P$ is the load applied on the tablet that causes diametral fracture of the tablet of diameter, $D$, and $t$ is the tablet thickness $(m)$.

Consolidation of the tablets, as given by the packing fraction $\left(P_{f}\right)$, is given by the equation:

$$
P_{f}=\frac{W}{\pi r^{2}+\lambda}
$$

where $W$ is the mean mass of tablets $(\mathrm{mg}), r$ is the radius $(\mathrm{m})$, and $t$ is the thickness $(\mathrm{m})$, $\lambda$ is the particle density of paracetamol used in the tablet formulation. The determination was done using the fluid displacement method. The density was $1.82 \mathrm{~g} \mathrm{~cm}^{-3}(9,10)$. The drug content uniformity in tablets was confirmed according to the BP method (11).

\section{Disintegration and dissolution tests}

Disintegration times of the tablets were determined in distilled water at $37 \pm 0.5^{\circ} \mathrm{C}$ using a disintegration tester (type ZT 121, Erweka, Germany). Determinations were made in quadruplicate.

The in vitro release profiles of paracetamol from the tablets were obtained in $900 \mathrm{~mL}$ phosphate buffer ( $\mathrm{pH}$ 5.8) maintained at $37.0 \pm 1{ }^{\circ} \mathrm{C}$ in a dissolution tester (Caleva 8ST, Germany) using the paddle method at $50 \mathrm{rpm}$. Samples $(5 \mathrm{~mL})$ were withdrawn and replaced with fresh medium at fixed time intervals. Paracetamol was assayed spectrophotometrically (Varian, Australia) as described in British Pharmacopoeia (11). The results are the means of six determinations.

\section{Data treatment}

In order to describe the kinetics of drug release from preparations, various mathematical equation modeles (zero-order, first-order, Higuchi) were tested (12):

$$
\begin{gathered}
Q_{\mathrm{t}}=k_{0} t \\
\ln Q_{\mathrm{t}}=\ln Q_{0}-k_{1} t \\
Q_{\mathrm{t}}=k_{\mathrm{H}} t^{1 / 2}
\end{gathered}
$$

where $Q_{\mathrm{t}}$ is the amount of drug released in time $t, Q_{0}$ is the initial amount of drug in the tablet and $k_{0}, k_{1}$ and $k_{\mathrm{H}}$ are the respective release rate constants for zero-order, first-order and Higuchi models. In order to define a model, that will represent a better fit for the formulations, dissolution data can be further analyzed by the Ritger and Peppas and Korsmeyer equation (13): 


$$
M_{\mathrm{t}} / M_{\infty}=k_{\mathrm{p}} t^{n}
$$

where $M_{t}$ corresponds to the amount of drug released in time $t, M_{\infty}$ is the total amount of drug that must be released at infinite time, $k_{\mathrm{p}}$ is a constant and $n$ is the release exponent indicating the type of drug release mechanism (13).

\section{Statistical analysis}

Statistical analysis was carried out by using the analysis of variance (ANOVA) with computer software SPSS 10. Tukey-Kramers multiple-comparison tests were used to compare the group data.

\section{RESULTS AND DISCUSSION}

Swelling of psyllium seeds was $683.3 \pm 51.1 \%$ (1g, $16.4 \pm 1.2 \mathrm{~mL})$. Sharma and Koul (7) reported $17.2 \mathrm{~mL}$ swelling for psyllium seeds in their study. The yield percentage of the mucilage extraction from Plantago psyllium seeds was $40.6 \%$ and the viscosity of its $1 \%$ aqueous dispersion was $0.531 \mathrm{~Pa}$. The $\mathrm{pH}$ of $1 \%$ aqueous solution of psyllium mucilage was $4.2 \pm 0.3$.

Table I shows the formulation composition. Lactose was used as filler, and Mg-stearate $(1 \%)$ was added to every formulation as lubricant. Table II compares the binding properties of paracetamol granules made with psyllium mucilage $(1-5 \%, m / m)$ and PVP and tragacanth $(1$ and $3 \%, m / m)$. The results showed that the mucilage at $5 \%(\mathrm{~m} / \mathrm{m})$ showed similar granule characteristics as PVP $3 \%(\mathrm{~m} / \mathrm{m})$. The percentage of fine particles in granules F1-F5 decreased with an increase in mucilage concentration $(p<0.001)$. There were no differences between fine particle percentages of F5 and F7 containing psyllium mucilage $5 \%$ and $3 \% \mathrm{PVP}$, respectively. The same results were observed for

Table I. Formulation composition of investigated paracetamol tablets

\begin{tabular}{|c|c|c|c|c|c|c|}
\hline \multirow{2}{*}{$\begin{array}{l}\text { Formulation } \\
\text { code }\end{array}$} & \multicolumn{5}{|c|}{ Formulation composition } & \multirow{2}{*}{$\begin{array}{l}\text { Total mass } \\
\quad(\mathrm{mg})\end{array}$} \\
\hline & $\begin{array}{l}\text { Paracetamol } \\
\qquad(\mathrm{mg})\end{array}$ & $\begin{array}{l}\text { Lactose } \\
(\mathrm{mg})\end{array}$ & $\begin{array}{l}\text { Psyllium mu- } \\
\text { cilage }(\mathrm{mg})\end{array}$ & $\begin{array}{l}\text { PVP } \\
(\mathrm{mg})\end{array}$ & $\begin{array}{l}\text { Tragacanth } \\
\text { (mg) }\end{array}$ & \\
\hline F1 & 325 & 325 & $6.5(1 \%)$ & - & - & 656.5 \\
\hline F2 & 325 & 325 & $13.0(2 \%)$ & - & - & 663.0 \\
\hline F3 & 325 & 325 & $19.5(3 \%)$ & - & - & 669.5 \\
\hline F4 & 325 & 325 & $26.0(4 \%)$ & - & - & 676.0 \\
\hline F5 & 325 & 325 & $32.5(5 \%)$ & - & - & 682.5 \\
\hline F6 & 325 & 325 & - & $6.5(1 \%)$ & - & 656.5 \\
\hline F7 & 325 & 325 & - & $19.5(3 \%)$ & - & 669.5 \\
\hline F8 & 325 & 325 & - & - & $6.5(1 \%)$ & 656.5 \\
\hline F9 & 325 & 325 & - & - & $19.5(3 \%)$ & 669.5 \\
\hline
\end{tabular}


Table II. Characteristics of paracetamol granules prepared with different concentrations of Plantago psyllium mucilage, $P V P$ and tragacanth

\begin{tabular}{ccccc}
\hline $\begin{array}{c}\text { Formulation } \\
\text { code }\end{array}$ & Fine ${ }^{\mathrm{a}}(\%)$ & $\begin{array}{c}\text { Bulk density } \\
\left(\mathrm{g} \mathrm{cm}^{-3}\right)\end{array}$ & $\begin{array}{c}\text { Tapped density } \\
\left(\mathrm{g} \mathrm{cm}^{-3}\right)\end{array}$ & Porosity $(\%)$ \\
\hline F1 & $12.2 \pm 1.7$ & $0.76 \pm 0.03$ & $0.82 \pm 0.02$ & 7.4 \\
F2 & $10.4 \pm 1.4$ & $0.72 \pm 0.03$ & $0.77 \pm 0.03$ & 6.9 \\
F3 & $7.5 \pm 1.1$ & $0.67 \pm 0.02$ & $0.73 \pm 0.02$ & 6.6 \\
F4 & $6.0 \pm 0.9$ & $0.63 \pm 0.01$ & $0.69 \pm 0.02$ & 6.3 \\
F5 & $3.7 \pm 0.6$ & $0.58 \pm 0.01$ & $0.63 \pm 0.01$ & 6.1 \\
F6 & $4.1 \pm 0.8$ & $0.62 \pm 0.01$ & $0.68 \pm 0.02$ & 6.4 \\
F7 & $4.0 \pm 0.7$ & $0.59 \pm 0.01$ & $0.63 \pm 0.02$ & 6.1 \\
F8 & $5.8 \pm 1.2$ & $0.67 \pm 0.02$ & $0.73 \pm 0.03$ & 6.5 \\
F9 & $5.3 \pm 1.1$ & $0.64 \pm 0.01$ & $0.69 \pm 0.02$ & 6.3 \\
\hline
\end{tabular}

a Mean $\pm \mathrm{SD}, n=10$.

bulk density, tapped density and porosity. The bulk density of granules containing mucilage decreased with increasing the mucilage concentration in F1 from $0.76 \pm 0.03 \mathrm{~g}$ $\mathrm{cm}^{-3}$ to $0.58 \pm 0.01 \mathrm{~g} \mathrm{~cm}^{-3}$ in F5 $(p<0.01)$. This decrease was observed for tapped density from $0.82 \pm 0.02 \mathrm{~g} \mathrm{~cm}^{-3}$ to $0.63 \pm 0.01 \mathrm{~g} \mathrm{~cm}^{-3}$ in F1 and F5, respectively $(p<0.01)$. The porosity decreased with the increase in mucilage concentration from F1 to F5 (7.38 \% to $6.09 \%$, respectively) too.

Table III compares the binding properties of paracetamol tablets with psyllium mucilage (F1-F5) and PVP and tragacanth (F6-F9). Psyllium mucilage containing tablets (F1-F5) showed significanty higher friability $(p<0.01)$, but were slower in disintegration.

Values of the tensile strength and friability for all formulations at relative density of 0.90 a representative of commercial tablets are presented in Table III. The values of hardness (from $3.85 \pm 0.24$ to $5.09 \pm 0.31 \mathrm{~kg} \mathrm{~cm}^{-2}$ in F1 and F5, respectively) and tensile strength (from $0.49 \pm 0.04$ to $0.71 \pm 0.08 \mathrm{MN} \mathrm{m}^{-2}$ in F1 and F5, respectively) increased with an increase in the concentration of mucilage, while friability decreased with the increase in mucilage concentration (from $1.54 \pm 0.08$ to $0.92 \pm 0.07 \%(\mathrm{~m} / \mathrm{m})$ in F1 and F5, respectively) for tablets prepared by wet granulation. The packing fraction increased with increasing the mucilage concentration from $0.22 \pm 0.01$ to $0.39 \pm 0.02$ in F1 an F5, respectively $(p<0.01)$, too. It is well known that polymers undergo plastic deformation, which subsequently leads to the formation of more solid bonds, resulting in tablets with more resistance to fracture and abrasion (14). However, when the polymer is "contaminated « by other materials such as the drug, the number of solid bonds between the particles decreases, leading to a decrease in the tensile strength of the tablet.

The drug content uniformity test showed that the drug concentration was $98.78-101.09 \%$. The disintegration time of the tablets is presented in Table III. The disintegration time increased with an increase in mucilage concentration. Statistical analysis showed a significant $(p<0.001)$ difference in disintegration times of the tablets (from $9.21 \pm 1.87$ to $26.27 \pm 1.53 \mathrm{~min}$ in F1 and F5, respectively) prepared with mucilage. These 
Table III. Characteristics of paracetamol tablets prepared with different concentrations of Plantago psyllium mucilage, PVP, and tragacanth

\begin{tabular}{ccccccc}
\hline $\begin{array}{c}\text { Formulation } \\
\text { code }\end{array}$ & $\begin{array}{c}\text { Hardness } \\
\left(\mathrm{kg} \mathrm{cm}^{-2}\right) \\
(n=10)^{\mathrm{a}}\end{array}$ & $\begin{array}{c}\text { Friability } \\
(\%, m / m) \\
(n=10)^{\mathrm{a}}\end{array}$ & $\begin{array}{c}\text { Tensile } \\
\text { strength } \\
\left(\mathrm{MN} \mathrm{m}^{-2}\right) \\
(n=10)^{\mathrm{a}}\end{array}$ & $\begin{array}{c}\text { Packing } \\
\text { fraction } \\
(n=10)^{\mathrm{a}}\end{array}$ & $\begin{array}{c}\text { Disintegra- } \\
\text { tion time } \\
(\mathrm{min})(n=4)^{\mathrm{a}}\end{array}$ & $\begin{array}{c}\text { Assay }(\%) \\
(n=20)^{\mathrm{a}}\end{array}$ \\
\hline F1 & $3.85 \pm 0.24$ & $1.5 \pm 0.1$ & $0.49 \pm 0.04$ & $0.22 \pm 0.01$ & $9.21 \pm 1.87$ & $99.24 \pm 3.02$ \\
F2 & $4.12 \pm 0.21$ & $1.2 \pm 0.1$ & $0.54 \pm 0.07$ & $0.28 \pm 0.01$ & $12.56 \pm 1.94$ & $101.09 \pm 2.14$ \\
F3 & $4.35 \pm 0.25$ & $1.0 \pm 0.1$ & $0.61 \pm 0.07$ & $0.32 \pm 0.02$ & $18.64 \pm 1.12$ & $98.54 \pm 2.12$ \\
F4 & $4.87 \pm 0.34$ & $0.9 \pm 0.1$ & $0.65 \pm 0.05$ & $0.35 \pm 0.01$ & $21.21 \pm 1.61$ & $99.54 \pm 2.47$ \\
F5 & $5.09 \pm 0.31$ & $0.9 \pm 0.1$ & $0.71 \pm 0.08$ & $0.39 \pm 0.02$ & $26.27 \pm 1.53$ & $99.31 \pm 2.04$ \\
F6 & $4.93 \pm 0.31$ & $0.8 \pm 0.1$ & $0.57 \pm 0.04$ & $0.30 \pm 0.01$ & $11.21 \pm 1.74$ & $98.78 \pm 1.95$ \\
F7 & $5.12 \pm 0.25$ & $0.7 \pm 0.1$ & $0.67 \pm 0.07$ & $0.37 \pm 0.02$ & $12.5 \pm 1.81$ & $99.51 \pm 2.16$ \\
F8 & $4.65 \pm 0.34$ & $0.8 \pm 0.1$ & $0.55 \pm 0.06$ & $0.28 \pm 0.02$ & $18.21 \pm 1.41$ & $99.67 \pm 1.64$ \\
F9 & $4.86 \pm 0.24$ & $0.8 \pm 0.1$ & $0.58 \pm 0.07$ & $0.31 \pm 0.01$ & $29.94 \pm 1.54$ & $99.43 \pm 2.11$ \\
\hline
\end{tabular}

a Mean \pm SD.

values were near the disintegration times of tablets which were prepared with tragacanth as a binder. Odeku and Fell (14) obtained similar results in paracetamol tablets which they prepared with khaya gum as binder.

Comparative dissolution profile (Fig. 1) shows that in psyllium mucilage containing tablets (F1-F5) the drug release decreases with an increase in mucilage content. However, statistical analysis showed that the drug dissolution increase in consecutive formulations (F1-F4) was not significant except for F1 and F3 ( $p=0.037)$ with mucilage concentrations increase from 1 to $3 \%$, resp. The drug release significantly increased in F5 in comparison with F4 $(p<0.001)$.

Results of the dissolution study showed faster dissolution in formulations containing PVP (F6 and F7) in comparison with other formulations containing either mucilage

Fig. 1. Dissolution of paracetamol from tablets prepared with psyllium mucilage (F1-F5), PVP (F6 and F7) and tragacanth (F8 and F9). Each point represents mean \pm SD of six experiments.

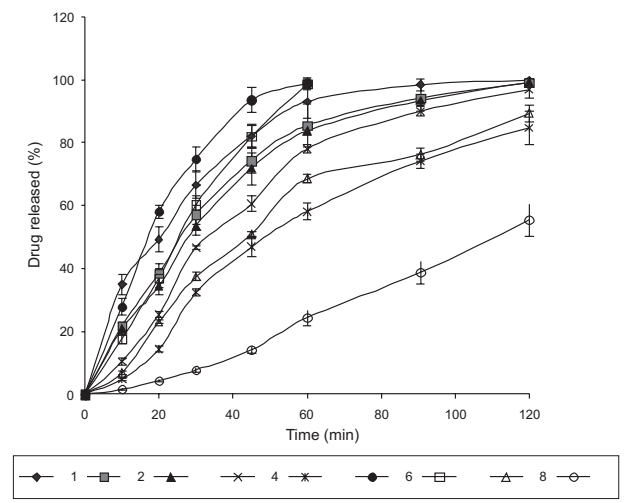


(F1-F5) or tragacanth ( $p<0.001$ for all investigations). In psyllium mucilage containing tablets (F1-F5), drug release was faster than that from F9 containing $3 \%$ tragacanth as a binder ( $p<0.001$ for all cases). Increase in mucilage concentration to $5 \%$ in F5 prolonged drug release in comparison with F8 $(p=0.008)$. Nokhodchi et al. (15) showed a similar effect of fenugreek mucilage on the release rate of propranolol hydrochloride from matrices. This study showed a comparatible effect of fenugreek mucilage on the release rate to that of the matrices with HPMC.

Dissolution rate data was analyzed based on the quoted equations and their results are listed in Table IV. Results showed that in formulations containing psyllium mucilage as a binder (F1-F5) the highest $R^{2}$ was achieved for the first-order model. The values of $n$ in the Peppas model showed that in F2 and F3, the mechanism of release was slightly complex. The results for F4 and F5 showed abnormal values of $n$.

Table IV. The Kinetics data of paracetamol release from tablets prepared with different concentrations of Plantago psyllium mucilage, PVP and tragacanth

\begin{tabular}{ccccccccccccccccc}
\hline & \multicolumn{1}{c}{$\begin{array}{c}\text { Formul } \\
\text { code }\end{array}$} & $\begin{array}{c}k_{0}(\% \\
\left.\mathrm{min}^{-1}\right)\end{array}$ & $R^{2}$ & $\mathrm{ss}$ & $\begin{array}{c}k^{1} \\
\left(\mathrm{~min}^{-1}\right)\end{array}$ & $R^{2}$ & ss & $\begin{array}{c}k_{\mathrm{H}}(\% \\
\left.\mathrm{min}^{-1 / 2}\right)\end{array}$ & $R^{2}$ & ss & $\begin{array}{c}k_{\mathrm{p}}(\% \\
\left.\mathrm{min}^{-n}\right)\end{array}$ & $n$ & $R^{2}$ & ss \\
\hline F1 & 0.0057 & 0.786 & 30495 & -0.053 & 0.989 & 1871 & 0.0873 & 0.898 & 3495 & - & - & - & - \\
F2 & 0.0067 & 0.831 & 21114 & -0.039 & 0.983 & 4578 & 0.1021 & 0.931 & 3021 & 0.0287 & 0.8749 & 0.998 & 11.1 \\
F3 & 0.0070 & 0.854 & 18604 & -0.040 & 0.967 & 8392 & 0.1054 & 0.943 & 5414 & 0.0289 & 0.8473 & 0.987 & 59.4 \\
F4 & 0.0077 & 0.879 & 5260 & -0.030 & 0.993 & 30351 & 0.1158 & 0.959 & 77843 & 0.0067 & 1.2109 & 0.985 & 272 \\
F5 & 0.0073 & 0.934 & 47769 & -0.017 & 0.999 & 57670 & 0.1070 & 0.986 & 425691 & 0.0020 & 1.4266 & 0.977 & 902 \\
F6 & 0.0137 & 0.868 & 8769 & -0.083 & 0.972 & 12547 & 0.1566 & 0.959 & 7331 & - & - & - & - \\
F7 & 0.0163 & 0.980 & 639 & -0.079 & 0.875 & 59772 & 0.1814 & 0.996 & 73728 & - & - & - & - \\
F8 & 0.0072 & 0.909 & 6206 & -0.019 & 0.986 & 25538 & 0.1066 & 0.975 & 173826 & 0.0034 & 0.971 & 1.3564 & 687 \\
F9 & 0.0050 & 0.993 & 85735 & -0.007 & 0.973 & 210082 & 0.0703 & 0.946 & 2536874 & 0.0005 & 0.998 & 1.4697 & 209 \\
\hline
\end{tabular}

$k_{0}$ - zero-order release rate constant, $k_{1}$ - first-order release rate constant, $k_{\mathrm{H}}$ - Higuchi model release rate constant, $k_{\mathrm{p}}$ - Peppas model release rate constant, $n$ - release exponent in Peppas model, $R^{2}$ - coefficient of determination, ss - sum of the error squares.

The results of kinetics analysis showed that in F8, formulation containing tragacanth, the highest $R^{2}$ was achieved with the first-order, but by increasing the concentration of tragacanth the best fittings were observed in the Peppas and zero-order models. The values of $n$ showed that the mechanism of drug release was based on polymer swelling in these formulations. 


\section{CONCLUSIONS}

In conclusion, we can say that psyllium mucilage at $5 \%(\mathrm{~m} / \mathrm{m})$ can exhibit good binding properties comparable to those of $3 \%(\mathrm{~m} / \mathrm{m})$ of PVP. This mucilage, as a natural compound, has advantages such as oral safety and low cost. The release profiles show the effect of this mucilage on retardation of drug dissolution.

Acknowledgment. - This work was supported by a grant from the research council of the Mazandaran University of Medical Sciences.

\section{REFERENCES}

1. C. Chebli and L. Cartilier, Cross-linked cellulose as a tablet excipients: A binding/disintegrating agent, Int. J. Pharm. 171 (1998) 101-110; DOI: 10.1016/S0378-5173(98)00161-6.

2. F. Eichie and A. E. Amalime, Evaluation of the binder effect of the gum mucilages of Cissus populnea and Acassia senegal on the mechanical properties of paracetamol tablets, Afr. J. Biotech. 6 (2007) 2211-2214.

3. B. Anroop, B. Ghosh, V. Parcha and S. Vasanti, Studies on Ocimum gratissimum seed mucilage: evaluation of binding properties, Int. J. Pharm. 325 (2006) 191-193; DOI: 10.1016/j.ijpharm.2006. 06.030 .

4. R. S. Okor, Plasto-elasticity of salicylic acid powders granulated with aqueous coacervated systems of certain acrylate methacrylate copolymers, J. West Afr. Pharm. 10 (1996) 38-40.

5. A. Zargari, Medicinal Plants, Vol. 4, $4^{\text {th }}$ ed., Tehran University, Tehran, 1993, pp. 536-537.

6. A. Koocheki, L. Tabrizi and M. Nassiri Mahallati, The effects of irrigation intervals and manure on quantitative and qualitative characteristics of Plantago ovata and Plantago psyllium, Asian J. Plant Sci. 6 (2007) 1229-1234.

7. P. K. Sharma and A. K. Koul, Mucilage in seeds of Plantago ovata and its wild allies, J. Ethnopharmacol. 17 (1986) 289-295; DOI: 10.1016/0378-8741(86)90118-2.

8. O. A. Odeku and J. T. Fell, Effects of the method of preparation on the compression, mechanical, and release properties of Khaya gum matrices, Pharm. Dev. Technol. 11 (2006) 435-441.

9. J. T. Fell and J. M. Newton, Determination of tablet strength by diametral compression test, J. Pharm. Sci. 59 (1970) 688-691; DOI: 10.1002/jps.2600590523.

10. E. T. Sugita, L. S. Roger and R. Irwin, Metrology and Calculations, in Remington: The Science and Practice of Pharmacy (Ed. A. R. Gennaro), 19th ed., Mack, Easton 1995, pp. 63-93.

11. British Pharmacopoeia, Vol. 1, HMSO, London 1993.

12. T. Higuchi, Mechanism of sustained action medication, theoretical analysis of rate of release of solid drugs dispersed in solid matrices, J. Pharm. Sci. 52 (1963) 1145-1149; DOI: 10.1002/jps. 2600521210.

13. R. W. Korsmeyer, R. Gurny, E. M. Doelker, P. Buri and N. A. Peppas, Mechanisms of solute release from porous hydrophilic polymers, Int. J. Pharm. 15 (1983) 25-35; DOI: 10.1016/0378-5173 (83)90064-9.

14. O. A. Odeku and O. A. Itiola, Evaluation of the effects of khaya gum on the mechanical and release properties of paracetamol tablet formulation, Drug Dev. Ind. Pharm. 29 (2003) 311-320; DOI: $10.1081 /$ DDC-120018205.

15. A. Nokhodchi, H. Nazemiyeh, A. Khodaparast, T. Sorkh-Shahn, H. Valizadeh and J. L. Ford, An in vitro evaluation of fenugreek mucilage as a potential excipient for oral controlled release matrix tablets, Drug Dev. Ind. Pharm. 34 (2008) 323-329; DOI: 10.1080/03639040701662594. 


\section{$S A \check{Z} E T A K$}

\section{Evaluacija svojstava vezanja sluzi sjemenki biljke Plantago psyllium}

MAJID SAEEDI, KATAYOUN MORTEZA-SEMNANI, FARSHAD ANSOROUDI, SAEED FALLAH i GHOLAMREZA AMIN

U radu je ispitivana neškodljivost i sigurnost uporabe sluzi ekstrahirane iz sjemenki biljke Plantago psyllium. Primjenjivost te sluzi kao veziva u farmaceutskim pripravcima ispitana je na tabletama paracetamola. Granule pripravljene s različitim koncentracijama sluzi uspoređene su s granulama s PVP-om i tragakantom. Sluz s udjelom $5 \%(\mathrm{~m} / \mathrm{m})$ usporediva je s otopinom PVP-a masenog udjela $3 \%$. Pripravljene tablete paracetamola ukazuju na to da ispitivana sluz može usporiti oslobađanje lijeka.

Ključne riječi: Plantago psyllium (Plantaginaceae), sluz, paracetamol, vezivo, oslobađanje Faculty of Pharmacy, Mazandaran University of Medical Sciences, Sari, Iran

Pharmaceutical Sciences Research Center, Mazandaran University of Medical Sciences, Sari, Iran Faculty of Pharmacy, Tehran University of Medical Sciences, Tehran, Iran 